\title{
SUSTAINING A SUSTAINABILITY REPORT BY MODIFYING TRIPLE BOTTOM LINE TO PENTAPLE BOTTOM LINE: AN IMAGINARY RESEARCH DIALOGUE
}

\author{
Eko Ganis Sukoharsono \\ University of Brawijaya
}

\begin{abstract}
The study is an imaginary research dialogue. The dialogue is between two scholars: Senior and Junior Researchers. To bring up their imagination, postmodernism is used to explore the dialogue. Both are trying to discuss the current issues on Sustainability Report Disclosures. The objective of the study is to explicate Sustainability Report Disclosures by modifying Triple Bottom Line to Pentaple Bottom Line. Postmodernism is used to open our minds of research report writings and arguments by using dialogue to introduce Pentaple Bottom Line in Sustainability Report Disclosures.

The result of the study is that Pentaple Bottom Line is a mode of comprehensive disclosures on the preparation of sustainability report by any organization either business or public, and either big or small. The Pentaple Bottom Line is 5 Ps: Planet, People, Profit, Phenotechnology and Prophet. Planet means to preserve natural environment as a balance of operational activities of an organizational contribution. People give its meaning that the balance with the welfare of people (internal and external organizations) or the community becomes important to contribute to the corporation. Proportion in providing justice in people's welfare is an effort to be balanced. Profit is an effort that is now dominant in achieving organizational performance must be balanced. Profit or welfare in economic aspects is important, but must be balanced with the other Ps. Phenotechnology is the fact that the existence or phenomenon of information technology must be an important part in maintaining the survival of the corporation. Prophet is a spiritual, mental, or spiritual balance in the process of preserving life of an organization.
\end{abstract}

Keywords: Triple Bottom Line, Pentaple Bottom Line, Sustainability Report 


\section{PROLOGUE}

I started some thoughts of this study by thinking what contributions are necessary to be added at the main theme of the Seminar. As declared, the Seminar is International Interdisciplinary Studies Seminar (IISS). I appreciated with an invitation addressed to me as one of the keynote speakers at the Seminar. The main theme of the Seminar is to promote mutual exchange between scientists and experts across the nations to discuss innovative ideas and contemporary environmental issue. The Seminar is expected to improve the dissemination of knowledge among various disciplines related to enviroment awareness, and encourage their collaboration, by providing a platform to exchange information on environmental conservation and education for sustainable development. It is an honor for me to be one of keynote speakers as one of among others from different nations: Japan, Malaysia and Thailand. I think this is a good opportunity for me to share a thought of some relevant contemporary issues on environment which is sustainability report. My thought is concerning the innovation of how to prepare a report of sustainability activities. Sustainability is a word that we could trace back since the early $18^{\text {th }}$ century. But, in fact, there was no any concept relating the word of sustainability concerning environment, society and economic impacts up to 1960s. It could be traced when Howard Bowen (1956) wrote the English book of Social Responsibility of Businessmen. But then, the word of sustainability booming when it was introduced by the Global Reporting Initiative in 1997. In 1997, Coalition for Economically Responsible Economies (Ceres) started a Global Reporting Initiative (GRI) aimed at developing a sustainability information disclosure framework. In 1999, the United Nations Environment Programme (UNEP) joined with Ceres as a partner in the GRI project. In 2000, the first GRI Sustainability Reporting Guidelines were issued and almost 50 companies issued sustainability reports using these guidelines. A year later, the GRI became an independent organization and subsequently relocated in the Netherlands. GRI was launched to establish reporting guidelines for the triple bottom line: economic, social, and environmental performance.

Referring to the main theme of the Seminar, the purpose of the study is to explicate the dialogue on Sustainability Report Disclosures by modifying Triple Bottom Line to Pentaple Bottom Line. To explicate the study, I use a framework of an imaginary research dialogue using the perspective of Postmodernism. The imaginary dialogue is between two persons: with naming Senior and Junior Researchers. Both graduated at the postgraduate university. Senior Researcher is a lady who has well knowledge on sustainability report, whereas Junior is a gentleman who has a competency on financial and non-financial reporting. Both are focusing on the discussions of sustainability report disclosures innovation.

Senior : Junior, do you know what is Sustainability Report?

Junior : Senior, it seems to me that there are two words should be defined at first.

Senior $\quad$ Yes, I agree with you ... (with curious to look around waiting the answer)

Senior : Thus, what are the definitions according to you? 
Junior : Even though I am Junior, I will think seriously concerning the two definitions:

Sustainability is a complex concept. The most often quoted definition comes from the UN World Commission on Environment and Development: "sustainable development is development that meets the needs of the present without compromising the ability of future generations to meet their own needs."

Report or Account is a document containing information organized in a narrative, graphic, or tabular form, prepared on ad hoc, periodic, recurring, regular, or as required basis.

Senior $\quad$ : Wow ... You did it very well, Junior. It seems both definitions are well constructed.

The definitions are the beginning of the study to understand a sustainability report through an imaginary research dialogue. The objective of the study is to explicate some issues on sustainability report disclosures by modifying from Triple Bottom Line to Pentaple Bottom Line.

\section{Method of Explication}

The study is postmodernism in nature. It explicates some issues on sustainability report disclosures by modifying the concept of Triple Bottom Line to Pentaple Bottom Line. Postmodernism is used as a distinct way to bring up ideas in researcher minds based on observed and unobserved phenomena of sustainability report (Sukoharsono, $2016,2018)$. Two researchers are made up to have a dialogue imaginarily. They are with the names of Senior and Junior. Senior is representing a female researcher who has good knowledge on sustainability report, whereas Junior is as a professional male researcher who has a competency on financial and non-financial reporting.

Senior : Junior, the idea using postmodernism is because it gives much open up our minds of the ways we do to write and explore our ideas. No one could stop our thinking.

Junior : Yes, you are right, Senior, for me, postmodernism is unstructured mode of writing. That is why, an imaginary research dialogue is one of objectives to explore some strategies that could be understood by readers.

Junior : Some references are collected as sources, and experiences are also as sources of knowledge.

GRI Standards are important to be used to understand the concept of reports.

Sustainability Reports prepared by listed companies in Indonesia Stock Exchange, e.g.

PT. Pertamina, PT. Pupuk Kaltim and PT. Bank Negara Indonesia

Senior : Definitely this is a research too.

Senior : Why it is not. Yes, it is. Imagination is energizing your thoughts and lives.

Junior : Explication means by giving explicit writing in a comprehensive way of thought, whereas imaginarily means to express a belief of thought that could energize our lives or the existed things. 


\section{How Is Sustainability Report Defined?}

The study is defining a sustainability report by exploring a dialogue between two researchers: Senior and Junior. Sustainability Report becomes an important unit word or phrase concerning the contribution to organization's accountability. Sustainability Report also becomes a mode to convince stakeholders for asking organization's performance.

Junior : Senior ... as I defined each individual word, now how do we understand a sustainability report?

Senior : Junior ... now is my turn to tell you about Sustainability Report or SR.

Senior : When we define Sustainability Report, we should refer to the GRI Standard 2016.

Senior : According to the GRI, Sustainability Report is an organization's practice of reporting publicly on its economic, environmental, and/or social impacts, and hence its contributions - positive or negative - towards the goal of sustainable development.

Senior : Junior, this is what Sustainability Report is defined. The importance here is concerning to some words which are:

1. Organization

2. Practice of Reporting

3. For public concern

4. Economic Performance

5. Social Performance

6. Environmental Performance

7. Positive

8. Negative

9. Goals of sustainable development

Junior : Senior ... it is so complex definitions. Thus, what does it mean by organization?

Senior : Well I give you one example of this. Organization here is meant that it could be private businesses, local and/ or central governments, NGOs, small, medium and/ or large organizations. It is very interesting concept of reporting.

The GRI Standards create a common language for organizations and stakeholders, with which the economic, environmental, and social impacts of organizations can be communicated and understood. The Standards are designed to enhance the global comparability and quality of information on these impacts, thereby enabling greater transparency and accountability of organizations.

Junior : Senior, this means that Sustainability report based on the GRI Standards could also provide a balanced and reasonable representation of an organization's positive and negative contributions towards the goal of sustainable development. Interestingly, the information made available through sustainability report allows internal and external stakeholders to form opinions and to make informed decisions about an organization's contribution to the goal of sustainable development. 
The dialogue is interesting to understand how sustainability report is defined. Basically, sustainability report is a report published by a company or organization about the economic, environmental and social impacts caused by its everyday activities. A sustainability report also presents the organization's values and governance model, and demonstrates the link between its strategy and its commitment to a sustainable global economy.

Sustainability report as GRI Standards designed can also help organizations to measure, understand and communicate their economic, environmental, social and governance performance, and then set goals, and manage change more effectively. A sustainability report is the key platform for communicating sustainability performance and impacts - whether positive or negative.

Senior : Junior, I do have something else to describe sustainability report where they can be considered as synonymous with other terms for nonfinancial reporting; triple bottom line reporting, corporate social responsibility (CSR) reporting, and more. It is also an intrinsic element of integrated reporting; a more recent development that combines the analysis of financial and non-financial performance.

Junior : Senior, why does sustainability report also consider as Triple Bottom Line report?

Senior : Junior, your question is interesting to be answered.

Senior : So far, to answer it, the basic principle of the GRI is using triple bottom line concept. I will explicate it in detail further. Please wait ...

\section{Triple Bottom Line Concept of Sustainability Report}

The triple bottom line (or known as TBL or $3 \mathrm{BL}$ ) is an accounting framework with three aspects: social, environmental (or ecological) and economic. Some organizations have adopted the TBL framework to evaluate their performance in a broader perspective to create greater business value. John Elkington claims to have coined officially published in 1999. He also described as 3Ps: People, Planet and Profit. In fact, he declared publicly that the triple bottom line since 1994.

Junior : (With insisting in mind, Junior is asking to Senior), Senior why was triple bottom line?

Senior : Triple bottom line is a framework consisted of 3Ps as the basic concept in developing the GRI Standards for sustainability report.

Senior : (She continues her thoughts), Historically, as in 1987, the United Nations World Commission on Environment and Development (World Commission) provided what has become a widely-used definition saying sustainability is the ability of society to "[meet] the needs of the present without compromising the ability of future generations to meet their own needs." But in fact, the definition is lack of specificity.

Senior : Its gaining momentum for sustainability was when triple bottom line adopted. The Triple Bottom Line provides a starting point for developing ways to identify and monitor actions that contribute to the three facets of sustainability: economy, social equity, and environment. 
Junior $\quad$ : Yes, I know the reason why triple bottom line was used. I think it was because the word of sustainability was needed to more specific and 'easy' to be understood publicly. That was why triple bottom line was inserted to strengthen and operationalize a sustainability report.

The GRI uses a conceptual framework of triple bottom line to unify a methodology as what has been used by accounting model as so called GAAP (generally accepted accounting principles). The framework is comprehended by adopting a model of a ten reporting principles (GRI Standards, 2016). The GRI then claims could help an organization manage its overall impact on the [Triple Bottom Line], as it can improve the quality and transparency of sustainability reporting and provide a reasonable and balanced presentation of performance. The GRI program has become a benchmark around the world for measuring, monitoring, and reporting corporate sustainability efforts. Ten (earlier, Eleven) reporting principles are used to produce a Triple Bottom Line report. The principles are implemented through use of 146 indicators. Economic indicators cover, for example, (1) sales, profits, and return on investment, (2) taxes paid, (3) monetary flows, and (4) jobs created. The social equity leg is measured by looking at criteria such as (1) labor practices, (2) community impacts, (3) human rights, and (4) product responsibility. The environmental leg is evaluated according to criteria including (1) air quality, (2) water quality, (3) energy used, and (4) waste produced. Through this reporting system and resulting publicly available reports, GRI provides a way for the public to examine claims of sustainability in light of actual practices. Companies Using the GRI.

Senior : Junior, here are the details of the triple bottom line:

\section{The First $\mathbf{P}$ is People, the social equity bottom line}

The people or social equity is understood as human capital bottom line. This focuses on labor and the community and region in which an organization needs and operationalize its business. This means that an organization needs to have a reciprocal social structure in which the well-being of organization, labor and other stakeholder interests are interdependent.

\section{The Second $\mathbf{P}$ is Planet, the environmental bottom line}

The planet or environmental bottom line is understood as natural capital bottom line. It refers to sustainable environmental practices. A triple bottom line organization endeavors to benefit the natural order as much as possible or at the least do no harm and minimize environmental impact. This means that the triple bottom line organization endeavor reduces its ecological footprint by, among other things, carefully managing its consumption of energy and nonrenewables and reducing manufacturing waste as well as rendering waste less toxic before disposing of it in a safe and legal manner.

\section{The Third $P$ is Profit, the economic bottom line}

The profit or financial is understood as economic bottom line, where the economic value created by the organization after deducting the cost of all inputs, including the cost of the capital tied up. It therefore 
differs from traditional accounting definitions of profit. In the original concept, within a sustainability framework, the "profit" aspect needs to be seen as the real economic benefit enjoyed by the host society. It is the real economic impact the organization has on its economic environment.

\section{Modifying Triple Bottom Line to Pentaple Bottom Line}

Triple bottom line is not without criticism. When we look at in detail of the GRI framework, we could find some other things needed to be inserted. As discussed previously, 3Ps are very basic frames to focus on the concept of the sustainability reporting. No one could deny that people, planet and profit are necessary to be disclosure to account to its stakeholders.

Junior : Senior, I believe that triple bottom line is not so comprehensive. Why?

Senior : Junior, you are so critical in this sense.

Senior : Junior, I think you have a good idea to criticize the existing GRI framework.

Junior : Well, my objective with the criticism is as a spirit to sustain the sustainability report. For me the report is needed to be more additional disclosure indicators.

Senior : Do you mean 3Ps are not enough?

Junior : Yes, it is exactly not enough.

Senior : What is your proposal to be added?

Junior : I would like to adopt what Sukoharsono (2018)'s ideas were discussed when he present a Green Accounting in Indonesia at the National Seminar of Mulawarman University. If John Elkington (1999) gives the Triple Bottom Line idea, also known as 3P: People, Profit and Planet, then this idea is the Pentaple Bottom Line (5Ps), namely People, Profit, Planet, Phenotechnology, and Prophet. Two additional indicators are to be inserted in it as so called Pentaple Bottom Line.

Junior $\quad: 5 \mathrm{P}$ is an expansive thought towards 3P. This gives the meaning that if an organization or institution or corporation wants to maintain its survival, then it must balance the 5P aspects: People, Profit, Planet, Phenotechnology and Prophet. There must be innovation ... Therefore from this innovation.

People give the meaning that the balance with the welfare of people (internal and external corporations) or the community is important to be contributed by the organization. Proportion in providing justice in people's welfare is an effort to be balanced.

The first $P$, People, is as a human capital bottom line, which has a spirit that an organization seeks to provide benefits and advantages to stakeholders and not to exploit or endanger any group of people. Its stakeholders include employees, customers, suppliers, communities relevant to the operation of the 
organization, investors, stockholders, government officials and academicians. The spirit of the first $P$ is to seek giving back by contributing to the strength and growth of its community with such things as health care and education.

Profit is an effort that is now dominant in achieving organizational performance must be balanced. Profit or welfare in economic aspects is important, but must be balanced with the other $P$.

Planet is the preservation of the natural environment must be championed by the organization/ corporation to be balanced. The natural environment makes humans must be protected and preserved, utilization and management must be balanced in the process and for generations to come. This is as a natural capital bottom line, which refers to the natural environment must be protected and preserved.

Phenotechnology is the fact that the existence or phenomenon of information technology must be an important part in maintaining the survival of an organization. Disclosures on phenotechnology could include the implementation of software, hardware, networking, telecommunication, and database.

Prophet is a spiritual, mental, or spiritual balance in the process of preserving life. An organization must be aware of the practices of spirituality. This includes disclosures of God Consciousness, Transcendental Awareness, Honesty, Self Contemplation Ability and Sincere Love.

\section{Epilogue: Pentaple Bottom Line As A New Framework of Sustainability Report \\ Senior : We are now coming to a conclusion \\ Junior : It is believed that Pentaple Bottom Line provides more comprehensive disclosure concerning a sustainability report. \\ Junior : Additional disclosures on phenotechnology and phophet could answer the current issues on the implementation of information technology and spiritual concern within an organization.}




\section{References:}

Bowen, Howard. 1953. Social Responsibility of the Businessmen. Harper \& Rowe: New York.

Elkington, John. 1999. Cannibals with forks : the triple bottom line of 21st century business. Oxford: Capstone.

Global Reporting Initiative. 2016. Consolidated Set of GRI Sustainability Reporting Standards 2016.

Sukoharsono, Eko Ganis and Dyah Ayu Widhayati. 2017. Sustainability Report and Creating Shared Value (CSV): Sustaining a Business of Urea Fertilizer Manufacture in the Case of Pupuk Kaltim Indonesia. Presented at: SIBRRDINRRU 2017 (Sydney) Conference on Interdisciplinary Business and Economics Research, 15th - 16th April 2017, Sydney, Australia

Sukoharsono, Eko Ganis. 2007. Green Accounting in Indonesia: Accountability and Environmental Issues. The International Journal of Accounting and Business Society. Vol.15. No 1. August. Pp.23-66.

Sukoharsono, Eko Ganis. 2008. Religion, Spirituality, and Philosophy: How Do They Work For An Accounting World? The 3rd Postgraduate Consortium in Accounting: Socio-Spiritual ..., Postgraduate Program University of Brawijaya, 8-9 September.

Sukoharsono, Eko Ganis. 2009. Spiritual Intelligence Definitions: Availability for Accounting Knowledge. Unpublished Working Paper. Faculty of Economics. University of Brawijaya

Sukoharsono, Eko Ganis. 2010. Metamorfosis Akuntansi Sosial dan Lingkungan: Mengkonstruksi Akuntansi Sustainabilitas Berdimensi Spiritual. Unpublished Naskah Pidato Guru Besar. Faculty of Economics. University of Brawijaya. Desember.

Sukoharsono, Eko Ganis. 2011. Green Accounting To Be A Serious Business of Accounting Discipline: An Imaginary Neo-Postmodernist Dialogue. Presented at the Plenary Session of the Grand Opening of the Accounting National Symposium (Simposium Nasional Akuntansi - SNA) XIV ACEH, INDONESIA 20-23 July 2011

Sukoharsono, Eko Ganis. 2018. Strategies to Improve the Sustainability in Promoting Transparency,

Accountability and Anti-Corruption: An Imaginary Dialogue. The International Journal of Accounting and Business Society. Vol.26. No 1. August.

United Nations. 2015. Transforming Our World: The 2030 Agenda for Sustainable Development

United Nations. 2016. UN E-Government Survey 2016. 